\title{
Aromatase is abundantly expressed by neonatal rat penis but downregulated in adulthood
}

\author{
S Jesmin'1, C N Mowa ${ }^{3}$, I Sakuma1, N Matsuda², H Togashi², M Yoshioka², \\ Y Hattori ${ }^{2}$ and A Kitabatake ${ }^{1}$ \\ ${ }^{1}$ Department of Cardiovascular Medicine, Hokkaido University Graduate School of Medicine, Sapporo, Japan \\ 2Department of Pharmacology, Hokkaido University Graduate School of Medicine, Sapporo, Japan \\ ${ }^{3}$ Department of Neurobiology, Northeastern Ohio Universities College of Medicine, Rootstown, Ohio, USA
}

(Requests for offprints should be addressed to I Sakuma; Email: j_subrina@yahoo.co.jp)

\begin{abstract}
Although synthesis of estrogen by male gonads has been well documented for over half a century, it is only recently that the role of estrogen in male reproductive events has gained appreciation. We recently reported abundant expression of estrogen receptor (ER)- $\alpha$ and $-\beta$ in different cell types of the rat penis, whose levels diminished with advancing age. The present study, which builds on data from the ER study, was designed to determine whether the penis is capable of generating its own local estrogen by examining evidence of the expression of aromatase, a microsomal enzymatic complex which irreversibly converts androgens to estrogens, using immunohistochemistry, Western blotting, in situ hybridization and real-time PCR analyses. Secondly, the effects of sex steroid hormones on penile aromatase were examined. Discrete aromatase immunoreactive cells were localized in primordial corpus cavernosum, corpus spongiosus and os penis, blood vessels and sensory corpuscle of glans penis. In situ hybridization signals corresponded with immunohistochemical findings. Western blot, enzyme immunoassay and real-time PCR analyses of rat penile samples revealed an age-dependent expression of aromatase and estrogen, with levels at week 1 almost resembling those of the ovary, but they decreased sharply by week 8 , and decreased further by week 35 . This expression pattern was strikingly similar to that of ER- $\alpha$ reported previously. Testosterone and diethylstilbesterol administered prenatally upregulate levels of aromatase mRNA and protein, and estrogen postnatally. Dihydrotestosterone upregulated aromatase mRNA and protein, but not estrogen. We conclude that estrogen acts via ER in a paracrine and/or autocrine manner to regulate penile events, particularly during development, and that estrogen synthesis is regulated by estrogen and androgens.
\end{abstract}

Journal of Molecular Endocrinology (2004) 33, 343-359

\section{Introduction}

The first report documenting synthesis of estrogen by male gonads was published over half a century ago (Zondek 1934, Goldzieher \& Roberts 1952, Leach et al. 1956, Morse et al. 1962, Attal 1969, Raeside \& Renaud 1983, Carreau et al. 1999). However, it is only in the past decade that interest in the role of estrogen in male fertility has increased, largely due to reports that exposure to environmental estrogens may have detrimental effects on male reproductive development and health, and that deletion of the estrogen receptor (ER)- $\alpha$ gene leads to impairment of male fertility
(Greene et al. 1939, Meistrich et al. 1977, Stillman 1982, Carreau et al. 1999, McKinnell et al. 2001). The role of estrogen in male fertility could include regulation of germ cell development or spermatogenesis, as reviewed by recent studies using mice lacking aromatase (Robertson et al. 1999).

In the male, estrogen is produced mainly by the testis, and to a lesser extent, by the brain and adrenal gland, in quantities overall far less than in the female (Carreau et al. 1999). However, although the ovaries, overall, produce more estrogen than the testes, it is interesting to note that local tissue concentrations of estrogen in male reproductive tissues, such as the efferent ducts, exceed the levels 
of circulating estrogen in females (Free \& Jaffe 1979). Equally interesting are recent revelations that circulating estrogen levels in adult males resemble those found in females during the early follicular phase and that levels in postmenopausal women are less than in age-matched males (Longcope et al. 1990, de Ronde et al. 2003).

Clearly, estrogen exerts strong effects on male reproductive events. These effects are principally mediated by the classical ER, ER- $\alpha$ and the recently discovered ER, ER- $\beta$ - members of the steroid/thyroid nuclear receptor superfamily which regulate gene transcription through estrogenresponsive elements (Koike et al. 1987, Kuiper et al. 1996). ER has been localized in the gonads and tracts of both males and females (Hess et al. 1997a, Sar \& Welsch 1999, Mowa \& Iwanaga 2000, 2001a,b, Jesmin et al. 2002). In male reproductive tissues other than the testis, the most intense signals of ER- $\alpha$ mRNA in adult rodents were localized in the epithelia of the efferent duct and initial segment of the epididymis, sites responsible for sperm concentration (Hess et al. 1997, Mowa \& Iwanaga 2001a). ER- $\alpha$ mRNA expression is also intense in the muscle layer of the vas deferens of the rat, while ER- $\beta$ mRNA is weakly expressed in the efferent duct, epididymis and vas deferens (Hess et al. 1997b, Mowa \& Iwanaga 2001a). We recently described the existence of ER-expressing cells in the penis, whose levels were expressed age-dependently, with the most intense signals observed during the perinatal period, but declining thereafter with age (Jesmin et al. 2002). Initial signals of ER- $\alpha$ were localized to the mesenchyme and subepithelial stroma, and later (postnatal day 2) to the corpus spongiosus, corpus cavernosum and urethral epithelia (Jesmin et al. 2002). ER- $\beta$ was initially detected by postnatal day 2 and was localized diffusely in corpus spongiosus and cavernosum in immature rats (Jesmin et al. 2002).

Because circulating levels of estrogen are low in the male during the perinatal period, we sought to determine whether the penis was the major source of estrogen acting on ER-expressing penile cells by examining the expression of aromatase. The cytochrome $\mathrm{P} 450$ aromatase ( $\mathrm{P} 450$ arom) is a microsomal enzymatic complex present in the endoplasmic reticulum of various vertebrate tissues and it irreversibly converts the aromatizable androgens, such as testosterone, to estrogens
(Lephart 1996, Pereyra-Martinez et al. 2001, Carreau et al. 2002, Wiszniewska 2002). Aromatase is expressed in a tissue-specific manner and is composed of two proteins - a ubiquitous NADPHcytochrome $\mathrm{P} 450$ reductase and a cytochrome P450 aromatase - which contain the heme and the steroid pocket (Lephart 1996, Carreau et al. 1999, 2002).

The present study localized aromatase in the penis; like ER, aromatase was expressed in an age-dependent manner. Sex steroids administered prenatally upregulate levels of aromatase mRNA and protein and estrogen postnatally.

\section{Materials and methods}

\section{Animals and treatments}

Male Wistar rats at postnatal days 1 and $3(n=30$ for each) were anesthetized by gaseous diethyl ether, killed and had their penises carefully harvested for Western blot analyses, immunohistochemistry, in situ hybridization and real-time PCR experiments. In addition, Wistar rats aged 1, 8 and 35 weeks were also anesthetized, killed and the penises were carefully harvested for Western blot analyses, ELISA and real-time PCR $(n=10$ for each). To determine the effects of varying estrogen:androgen ratios on aromatase expression, rats at day 10 of pregnancy were injected subcutaneously every alternate day until parturition with one of the following sex steroid hormones, dissolved in $0 \cdot 1 \mathrm{ml}$ sesame oil: (1) diethylstilbesterol (DES; Sigma, St Louis, MO, USA) $10 \mu \mathrm{g} /$ rat (high dose), $0 \cdot 1 \mu \mathrm{g} /$ rat (low dose); (2) dihydrotestosterone propionate (DHT; Sigma) $12.5 \mathrm{mg} / \mathrm{rat}$; and (3) testosterone propionate (Sigma) $1 \mathrm{mg} / \mathrm{rat} \quad(n=3$ mothers for each treatment). Pregnant rats, of equivalent gestational age (day 10), served as controls and were treated with an equivalent volume $(0 \cdot 1 \mathrm{ml})$ of sesame oil. After birth, the neonatal rats (pups) were treated at postnatal day 0 and day 2 with the sex steroid hormones (DES: $0.005 \mu \mathrm{g} / \mathrm{pup}$ (low dose), and $0.5 \mu \mathrm{g} / \mathrm{pup}$ (high dose); DHT: $750 \mu \mathrm{g} /$ pup; testosterone: $50 \mu \mathrm{g} / \mathrm{pup})$ dissolved in $50 \mu \mathrm{l}$ sesame oil. Age-matched control pups were treated with an equivalent volume $(50 \mu \mathrm{l})$ of sesame oil and processed as the treated groups. All the pups were killed on the third day after anesthetizing them with gaseous diethyl ether. 
Penile tissues were carefully harvested and processed as described below. Ovaries from pregnant or adult rats were used as positive control tissue for aromatase. All procedures were carried out in accordance with the regulations laid down by the Hokkaido University School of Medicine Animal Care and Use Committee.

\section{Characterization of antisera}

A number of antisera of aromatase were initially tested in rat penile tissues for immunohistochemistry. In our hands, CYP19 C-16 (Santa Cruz Biotechnology, Santa Cruz, CA, USA), an affinity purified goat polyclonal antibody raised against a peptide at the carboxyl terminus of human CYP19, and OBMMCA2077 (Oxford Biomarketing, Oxford, UK), a mouse anti-human cytochrome P450 synthetic peptide corresponding to amino acids 376-390, produced the most consistent robust signals. Thus, these antisera were used in the present study. Controls included omission of the primary antiserum, and omission of the secondary antibody.

\section{Immunofluorescence staining}

For immunohistochemical studies of aromatase, tissue specimens were fixed in $4 \%$ buffered formalin solution, dehydrated and then embedded in paraffin. The tissues were sliced in $4 \mu \mathrm{m}$ sections transversely, deparaffinized and treated for $10 \mathrm{~min}$ with citrate buffer $(10 \mathrm{mM}$ citric acid, $\mathrm{pH} 6 \cdot 0)$ in a microwave oven $(750 \mathrm{~W})$ before immunostaining. In another set of experiments, frozen tissue samples were cut by cryostat in $8 \mu \mathrm{m}$ sections, fixed in acetone and air-dried. To prevent non-specific staining by secondary antibody, the sections were blocked by non-immune serum $(1 \%$ bovine albumin in Tris) for $30 \mathrm{~min}$ at room temperature. After overnight incubation at $4{ }^{\circ} \mathrm{C}$ with primary antibodies, the sections were rinsed in phosphate buffer solution and then exposed to the fluorescence secondary antibody, Cy3-conjugated AffiniPure anti-mouse IgG or fluoresceinconjugated AffiniPure rabbit anti-goat IgG (Jackson ImmunoResearch Laboratories, Westgrove, PA, USA) for $2 \mathrm{~h}$, according to the manufacturer's instructions. The samples processed without primary antibodies served as negative controls. Immunofluorescence images were observed under a Laser Scanning Confocal Imaging System (MRC-1024, Bio-Rad Laboratories, Hemel Hempstead, Herts, UK). In our hands, the intensity of aromatase immunoreactivity in frozen tissue sections was stronger compared with paraffinembedded tissues.

\section{Western blot analysis}

After careful sampling of the penises and ovaries, the tissues (penises and ovaries) were rinsed in phosphate-buffered saline (PBS) on ice, minced with scissors, homogenized, and then centrifuged at $1000 \mathrm{~g}$ for $15 \mathrm{~min}$ to pellet any insoluble material. The total protein concentration of the supernatant was determined by the method of Lowry et al. (1951), with BSA as standard. Samples $(10 \mu \mathrm{g})$ were run on SDS-PAGE, using $8 \%$ polyacrylamide gel, and electrotransferred to a polyvinylidine difluoride filter (PVDF) membrane. To reduce non-specific binding, the PVDF was blocked for $60 \mathrm{~min}$ at room temperature in Tris-buffered saline (TBS: $20 \mathrm{mM}$ Tris-HCl, $500 \mathrm{mM}$ NaCl, pH 7.5) containing 1\% albumin. Thereafter, the PVDF was washed three times for $5 \mathrm{~min}$ in TBS-Tween buffer (TTBS: $20 \mathrm{mM}$ Tris-HCl, $500 \mathrm{mM} \mathrm{NaCl}, 0 \cdot 05 \%$ Tween 20, pH 7.5) and incubated overnight at $4{ }^{\circ} \mathrm{C}$ with specific antibody (1:200 dilution for aromatase) in TTBS containing 1\% albumin. After extensive washing with TTBS, the PVDF was incubated with horseradish peroxidase-conjugated anti-mouse or anti-goat antibody (Amersham, UK) diluted at 1:5000 in TTBS containing $1 \%$ albumin at room temperature for $60 \mathrm{~min}$. Then, the PVDF was washed for $5 \mathrm{~min}$ twice in TTBS and washed for $5 \mathrm{~min}$ in TBS. The blots were visualized using the enhanced chemiluminescence detection system (Amersham), exposed to X-ray film for $5 \mathrm{~min}$, and analyzed by image analysis software from NIH produced by Wayne Rasband (National Institute of Health, Bethesda, MD, USA; http:// rsb.info.nih.gov/nih-image/download.html). The results are expressed as a percentage of the band obtained from the ovary in each experiment. To check for protein loading/transfer variations, all blots were stained with Ponceau Red (washable, before incubation with antibodies) and with Coomassie Brilliant Blue. The intensity of total protein bands per lane was evaluated by densitometry. Negligible loading/transfer variation was observed between samples. 


\section{Generation of the aromatase polyclonal antibody and tissue ELISA}

The ELISA technique was used to test for penile aromatase and estrogen concentrations to supplement Western blot data. Because there is no aromatase antibody suitable for determining local aromatase concentration in tissues using ELISA, we developed a new antibody specific for aromatase. Mice were immunized with the peptide CALEDDVIDGYPVKKG, representing amino acid residues 376-390 of human aromatase, and serum was collected and titrated. Antibodies were affinity-purified over Amino-Link columns (Pierce Biotechnology, Rockford, IL, USA), conjugated with immunogen and eluted with $0 \cdot 1 \mathrm{M}$ glycine, $\mathrm{pH}$ 3. The new aromatase antibody generated was validated by Western blot. Observation of a single band at the expected molecular mass allowed the use of the antibody in ELISA. Moreover, the specificity of the aromatase antibody was further verified by isolation of an aromatase peptide (Immunobion, Sapporo, Japan), which was then used for the pre-adsorption test. The newly generated antibody was purified by peptide affinity column and then used for ELISA. Elutes were dialyzed against PBS and kept frozen in aliquots at $-80{ }^{\circ} \mathrm{C}$. Biotinylated primary antibodies were prepared using Biotin-(AC5)2-Osu (Dojin, Kumamoto, Japan). Samples, including standards of known target protein concentration and unknowns, were pipetted into wells coated with specific antibody. A second biotinylated antibody $\mathrm{IgG}$ was added. Samples were incubated for $4 \mathrm{~h}$ at room temperature and then aspirated to remove any excess or unbound biotinylated antibody. The enzyme streptavidin-peroxidase, which binds to the target protein-bound biotinylated antibody, was added. After a second incubation and washing to remove any unbound enzyme, substrate solution was added. This solution acts on bound enzyme to produce color. Absorption of the colored product was measured by spectrophotometry.

\section{In situ hybridization}

Specific 60-basepair (bp) long oligonucleotides complementary to either a $5^{\prime}$-region, i.e. 221281 bp (Aro 5' ologo, 5'-CGA-CAA-GAA-TCTGCG-ATG-GGA-AAT-GAG-AGG-CGG-GATTCG-CAG-ACA-GTA-GCG-AGG-ACG-TGG-3'), or the heme-binding region, i.e. $1351-1411 \mathrm{bp}$ (Aro 3' ologo, 5'-CAC-CAT-GGC-GAT-GTACTT-CGC-AGC-ACA-GCG-TGG-GGG-CGAAAG-CCA-AAT-GGC-TGA-AAA-TA-3'), of the rat cytochrome P450 aromatase cDNA (Lauber \& Lichtensteiger 1994) were purchased. Both probes produced almost the same signal, but the latter probe produced the most robust and consistent signal. The oligonucleotides were labeled with ${ }^{35} \mathrm{~S}-\mathrm{dATP}$, using terminal deoxyribonucleotidyl transferase (Promega, Madison, WI, USA) at a specific activity of $0.5 \times 10^{9}$ d.p.m. $/ \mu \mathrm{g}$ DNA.

Tissues (penis or ovary) were rapidly removed and frozen in liquid nitrogen. Cryostat sections, $15-20 \mu \mathrm{m}$ in thickness, were prepared and mounted on glass slides precoated with 3-aminopropyltriethoxysilane. The in situ hybridization protocol used has been described in detail previously (Mowa \& Iwanaga 2000). Briefly, tissue sections were fixed in $4 \%$ paraformaldehyde for $10 \mathrm{~min}$ and acetylated with $0 \cdot 25 \%$ acetic anhydride in $0 \cdot 1 \mathrm{M}$ triethanolamine- $\mathrm{HCl}(\mathrm{pH} 8 \cdot 0)$ for $10 \mathrm{~min}$. Slide-mounted sections were prehybridized for $2 \mathrm{~h}$ in a buffer containing $50 \%$ formamide, $0 \cdot 1 \mathrm{M}$ Tris-HCl $(\mathrm{pH} 7 \cdot 5), 4 \times \mathrm{SSC}(1 \times \mathrm{SSC} ; 150 \mathrm{mM}$ $\mathrm{NaCl}$ and $15 \mathrm{mM}$ sodium citrate), $0.02 \%$ Ficoll, $0.02 \%$ polyvinylpyrrolidone, $0.02 \%$ bovine serum albumin, $0.6 \mathrm{M} \mathrm{NaCl}, 0.25 \%$ SDS, $200 \mu \mathrm{g} / \mathrm{ml}$ tRNA, $1 \mathrm{mM}$ EDTA and $10 \%$ dextran sodium sulfate. Hybridization was performed at $42{ }^{\circ} \mathrm{C}$ for $10 \mathrm{~h}$ in the prehybridization buffer supplemented with 10000 c.p.m./ $\mu{ }^{35}$ S-labeled oligonucleotide probes. The slides were washed at room temperature for $20 \mathrm{~min}$ in $2 \times \mathrm{SSC}$ containing $0 \cdot 1 \%$ sarkosyl and twice at $55^{\circ} \mathrm{C}$ for $40 \mathrm{~min}$ in $0 \cdot 1 \times \mathrm{SSC}$ containing $0 \cdot 1 \%$ sarkosyl. The sections were either exposed to Hyperfilm- $\beta$ max (Amersham) for 4 weeks or dipped in Kodak NTB2 nuclear track emulsion and exposed for 4-8 weeks.

\section{Specificity of oligonucleotide probe}

The specificity of the oligonucleotide probes for in situ hybridization was determined by labeling $15-\mu \mathrm{m}$ cryostat sections of ovary from pregnant rats as positive control tissue. Corpora lutea of pregnant rats possess abundant levels of aromatase mRNA (Lauber et al. 1994). Furthermore, the specificity of the probes was confirmed by the disappearance of signals when excess doses of the corresponding non-labeled $\left({ }^{35} \mathrm{~S}-\mathrm{dATP}\right)$ anti-sense oligonucleotides 
(cold) were added to the labeled anti-sense oligonucleotides (hot) hybridization fluid. Consistent aromatase mRNA signals above background levels were considered positive and were subjectively scored as weak, moderate or strong.

\section{RNA preparation and real-time quantitative PCR}

Total RNA samples were prepared from tissues by the guanidinium thiocyanate-phenol-chloroform single-step extraction method with Isogen (Nippon Gene, Toyama, Japan), used routinely in our laboratory (Matsuda et al. 1999). After isolation, treatment with DNaseI and quantification, RNA was reverse-transcribed to cDNA by the use of a ReverTra Ace (TOYOBO, Osaka, Japan).

The single-stranded cDNA was then used in real-time quantitative $\mathrm{PGR}$ to evaluate relative expression levels of aromatase mRNA. DNA amplification was performed in the Applied Biosystems (ABI 7900HT) real-time PCR machine using the GeneAmp 7900HT Sequence detection system software (Perkin-Elmer Corp., Foster City, CA, USA) and the detection was determined by measuring the binding of the fluorescence dye SYBR Green I to double-stranded DNA. The PGR reactions were set up in microtubes in a volume of $20 \mu \mathrm{l}$. The reaction components were $2 \mu \mathrm{l} \mathrm{cDNA}$ synthesized in $10 \mu \mathrm{l}$ of $2 \times$ SYBR Green master mix (Perkin-Elmer Corp.) and $0.4 \mu \mathrm{M}$ of each pair of oligonucleotide primers, as described above. The program was performed as follows: an initial step at $95{ }^{\circ} \mathrm{C}$ for $10 \mathrm{~min}$, and then 40 cycles of $95^{\circ} \mathrm{C}$ for $15 \mathrm{~s}$ and $60{ }^{\circ} \mathrm{C}$ for $60 \mathrm{~s}$. Regression curves were drawn for each sample and the relative amount of aromatase mRNA was calculated from the threshold cycles with the instrument's software (SDS 2.0), according to the manufacturer's instructions. The PCR products were analyzed by gel electrophoresis, to confirm the specificity of the generated products. Relative expression levels of aromatase were normalized to the geometric mean of the two internal control genes, $\beta$-actin and glyceraldehyde-3-phosphate dehydrogenase (G3 $\mathrm{PDH})$. The primer sequences for real-time PCR were obtained from the Genebank, accession number NM-017085 (forward, CCT GGA GA TGA CGT GAT TG, position 1189; reverse, CGA TGT ACT TCG CAG CAG AG, position 1385), yielding a product of $197 \mathrm{bp}$.

\section{Measurement of $17 \beta$-estradiol in penile tissues by enzyme immunoassay (EIA)}

For determining tissue estrogen levels, the penile and ovarian tissues were washed in cold PBS just after tissue harvest and snap frozen on dry ice. The tissues were homogenized in 0.1 molar (M) Tris-HCl (pH 7.2) buffer by a high speed homogenizer, at a consistent ice-cold temperature, centrifuged at $1000 \boldsymbol{g}$ for $15 \mathrm{~min}$ to pellet any insoluble material, and thereafter the protein concentrations were measured. Finally, the local tissue concentrations of $17 \beta$-estradiol were quantified using an enzyme immunoassay kit (ESTRADIOL EIA, PANTEX, Santa Monica, CA, USA), according to the manufacturer's instructions. The specificity of this kit has previously been confirmed in our laboratory using various types of rat tissue including serum, plasma, ovary, brain and penis. The values obtained were compared with those of the Rodent Estradiol ELISA Test Kit (Endocrine Technologies, Inc., Newark, CA, USA). The lowest level of $17 \beta$ estradiol detectable by the kit used in this study is $4.6 \mathrm{pg} / \mathrm{ml}$. Intra-assay and interassay coefficients of variation $(\% \mathrm{CV})$ were 5.9 and 5.2 respectively.

\section{Statistical analysis}

Data are presented as means \pm S.D. Statistical assessment of the data was performed by ANOVA with multiple comparisons by Fisher's protected least significance $t$-test. $P$ values less than 0.05 were considered significant.

\section{Results}

\section{Characterization of aromatase antisera and immunofluorescence}

Immunofluorescence staining for aromatase protein showed that its expression was localized to the penis spongiosus, penis cavernosus, urethra, sensory corpuscle of glans penis, blood vessel, dorsal nerve and primordial os penis at postnatal day 1 (Fig. $1 \mathrm{~A}-\mathrm{K}$ ). In penile spongiosus, aromatase was expressed in both stromal and muscle cells. The observed immunoreactivity of aromatase was considered specific because primary antibodies (data not shown) or secondary antibodies alone showed no staining in the penile spongiosus, cavernosus or urethra. A representative photograph 

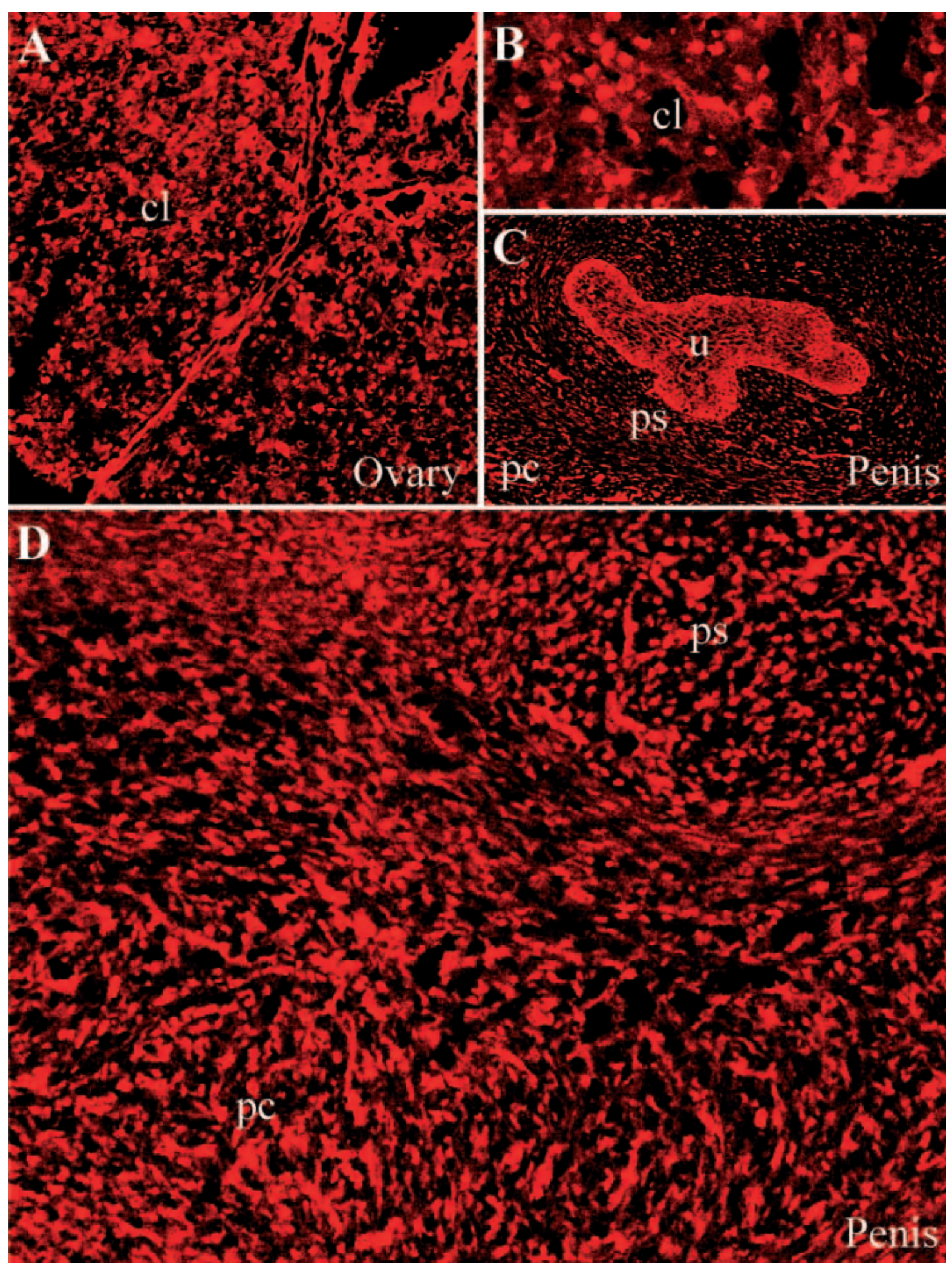

Figure $1(A)$ to $(D)$. 

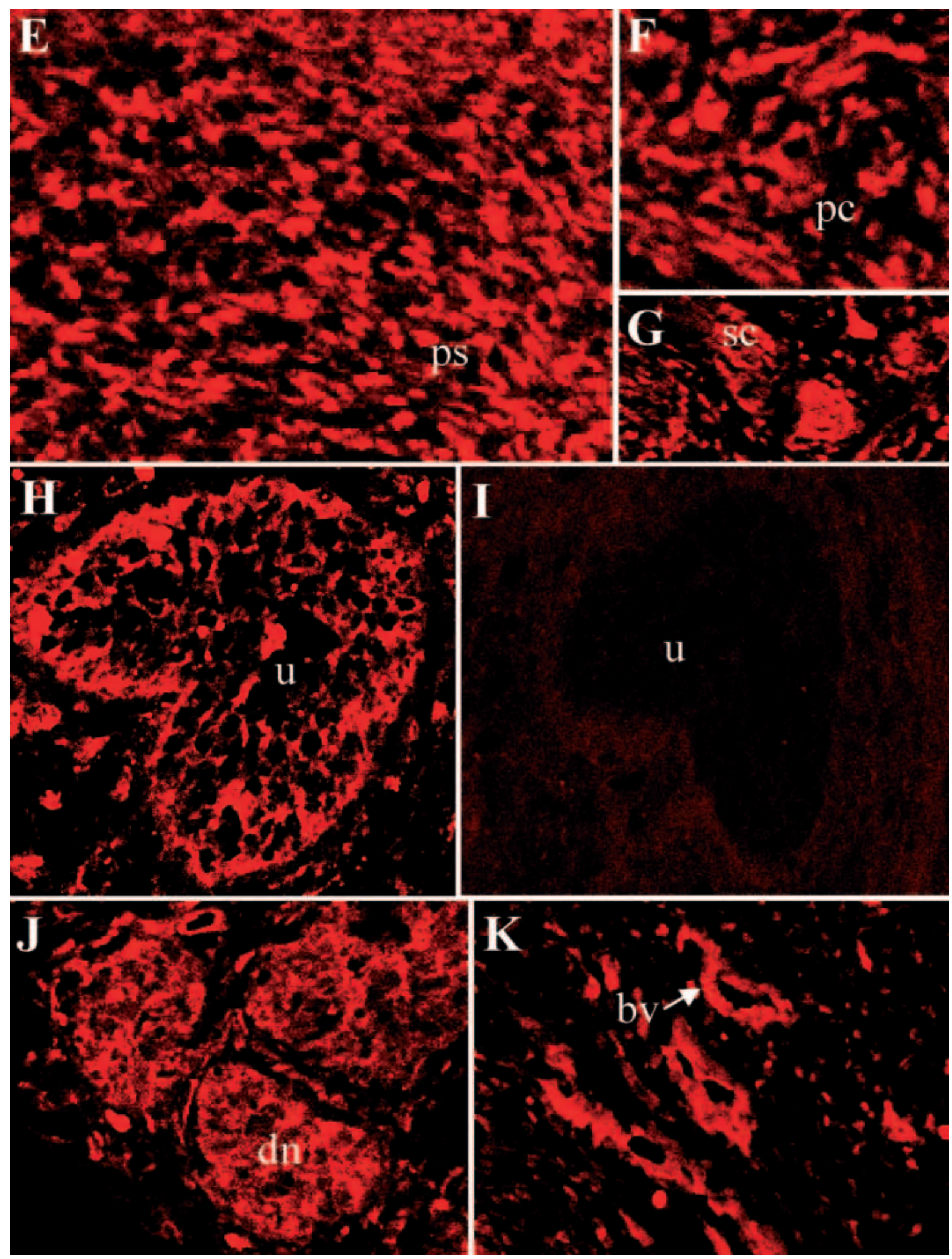

Figure $1(E)$ to $(K)$. 
of urethra $(\mathrm{u})$ at postnatal day 1 obtained by omission of the primary antibody served as a negative control (Fig. 1I). Furthermore, sections of ovaries from adult female pregnant rats stained with aromatase showed discrete immunoreactivity in the corpus lutea and granulosa. It is noteworthy that, in both ovary and penis, aromatase immunolabeling was localized in cytoplasm, as expected, and not in the nucleus (Fig. $1 \mathrm{~A}-\mathrm{K}$ ).

\section{In situ hybridization}

In situ hybridization studies showed intense to moderate and diffused signals of aromatase mRNA in spongiosus, cavernosus, urethra, glans penis, sensory corpuscle of glans penis and neurovascular bundles of postnatal day 3 penis (Fig. 2). Both basal and luminal epithelium of the urethra showed aromatase mRNA expression. The most intense signals were observed in penile spongiosus, penile cavernosus, glans penis and sensory corpuscles of glans penis. Only moderate amounts of aromatase mRNA were detected in neurovascular bundles and urethra.

\section{Western blot analysis}

Immunoblot analysis of the ovary and penises showed a single band with a molecular mass of $\sim 54 \mathrm{kDa}$, which matched the molecular mass of aromatase (Fig. 3). Quantification of the immunoblot bands by densitometry revealed a decrease in the levels of penile aromatase protein with age. When levels of penile aromatase protein were expressed as a percentage of aromatase protein of the ovary, they were $85 \pm 11 \%$ at 1 week $(P<0.001), 37 \pm 7 \%$ at 8 weeks $(P<0 \cdot 001)$ and $13 \pm 4 \%$ at 35 weeks of postnatal age $(n=5$; $P<0.001)$ (Fig. 3). These findings were also confirmed by immunofluorescence (data not shown). Moreover, no band was observed when aromatase antiserum was pre-adsorbed with the immunizing peptide (data not shown).

\section{Real-time PCR}

Consistent with the results of immunoblot, aromatase gene expression in penile tissues was decreased in a time-dependent manner (Fig. 4B). Ovarian tissue was used as a positive control. In situ hybridization experiments also showed an agerelated decrease of aromatase mRNA expression in penile tissues (data not shown).

\section{Quantitation of aromatase and 17 $\beta$-estradiol in penile tissues by ELISA and EIA}

The ELISA technique, using antibody generated in our laboratory, also showed a time-dependent decrease in levels of penile aromatase protein, consistent with the data obtained with immunoblot described above. As with Western blots, the pregnant ovary was used as a positive tissue (Fig. 4A). Furthermore, we measured the tissue concentration of estrogen in the penis to determine whether penile aromatase was functional or was capable of irreversibly converting androgens to estradiol. The estrogen concentration in the 1-week-old penis was $23 \pm 6 \mathrm{pg} / \mathrm{mg}$ compared with $46 \pm 8 \mathrm{pg} / \mathrm{mg}$ in the positive control tissue (ovary). By week 8 of age, the penile estrogen concentration dropped by about a half, to $13 \pm 3 \mathrm{pg} / \mathrm{mg}$, and by threefold of week 1 levels at 35 weeks of age $(9 \pm 3 \mathrm{pg} / \mathrm{mg}$ ) (Fig. 4C), a trend which interestingly resembles that of aromatase concentrations.

\section{Effects of sex steroid hormone treatment on levels of penile aromatase}

Treatment of pregnant mothers from day 10 $(10 \mu \mathrm{g}$, on alternate days) and neonates from birth

Figure $1(A-D)$ Immunofluorescence of aromatase in the rat penis and ovary. (A) Aromatase, stained red, is expressed in the corpus luteum (cl) of the ovary of pregnant rats. Low magnification $(\times 100)$. (B) Ovarian aromatase at high magnification $(\times 400)$. Immunoreactivity is clearly seen in the cytoplasm of the cells. (C) Aromatase distribution in the penis at postnatal day 1. Positive staining (red) is localized to the penis spongiosus (ps), urethra (u) and penis cavernosus (pc). Low magnification $(\times 100)$. (D) Immunoreactivity of aromatase in the penis spongiosus (ps) and penis cavernosus (pc) at high magnification $(\times 200)$. $(E-K)$ Immunofluorescence of aromatase in the rat penis at postnatal day 1. Positive immunoreactivity is localized in the cytoplasm of penis spongiosus (ps) and penis cavernosus $(p c)$ cells (magnification $\times 400)(E, F)$, sensory corpuscle $(s c)$ of glans penis (magnification $\times 200)(G)$, and urethra $(\mathrm{u})($ magnification $\times 200)(\mathrm{H})$. (I) Omission of primary antibody showed no immunoreactivity in the urethra (u), indicating the specificity of the antibody (magnification $\times 200$ ). Positive staining was also observed in dorsal nerve $(\mathrm{dn})($ magnification $\times 200)(\mathrm{J})$, and blood vessels $(\mathrm{bv})($ magnification $\times 200)(\mathrm{K})$. 


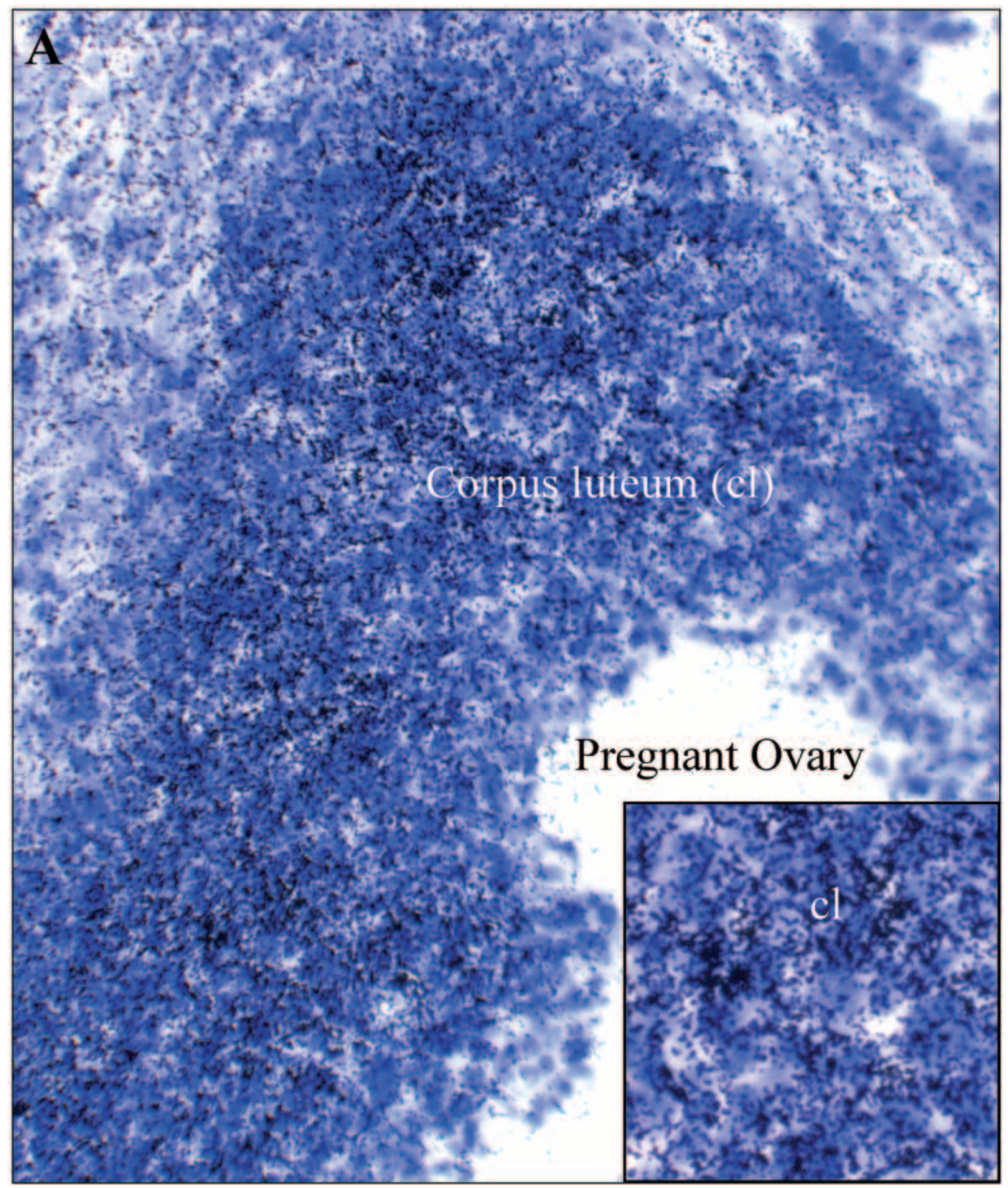

Figure $2(A)$. 


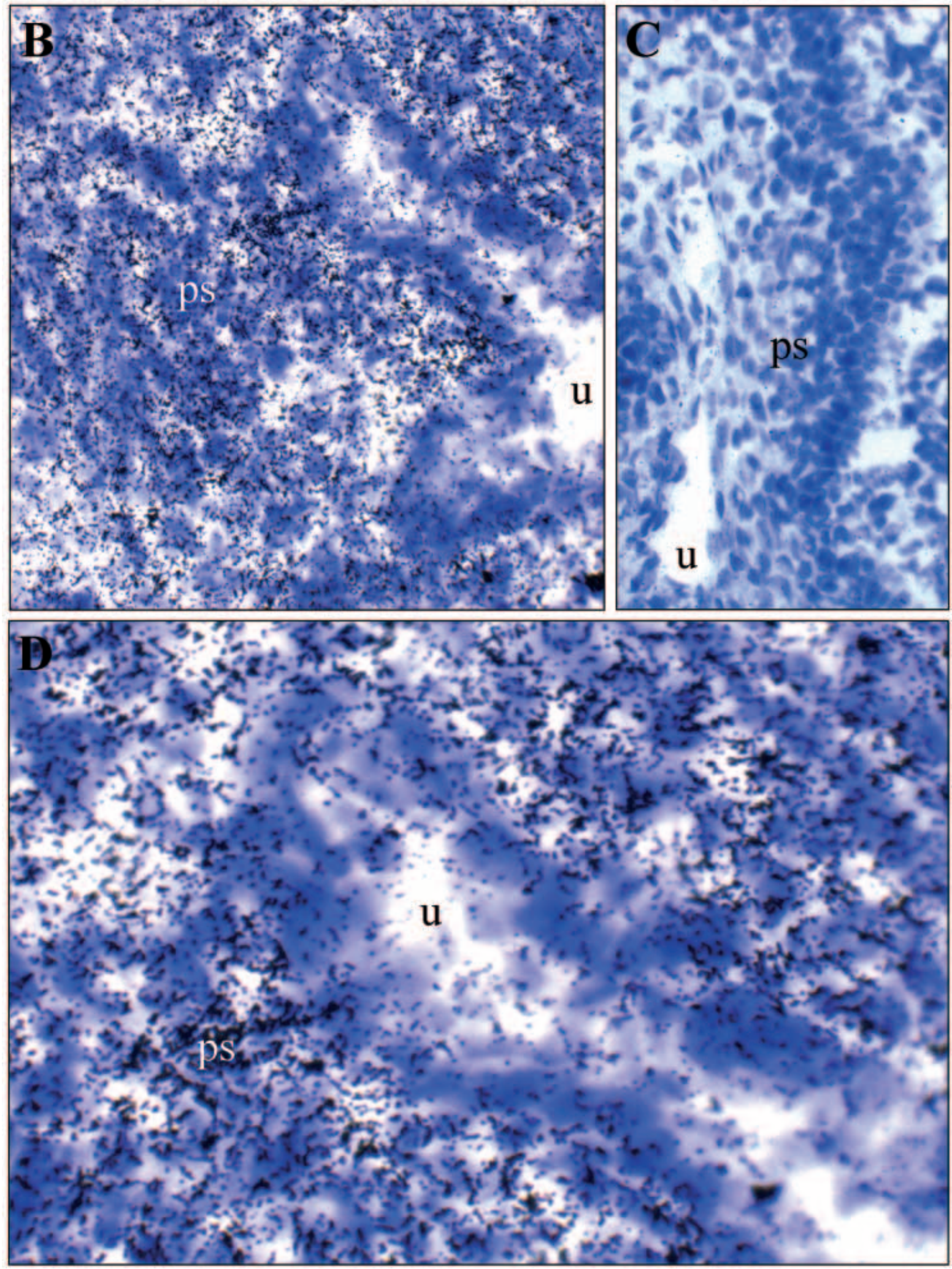

Figure $2(B)$ to $(D)$. 

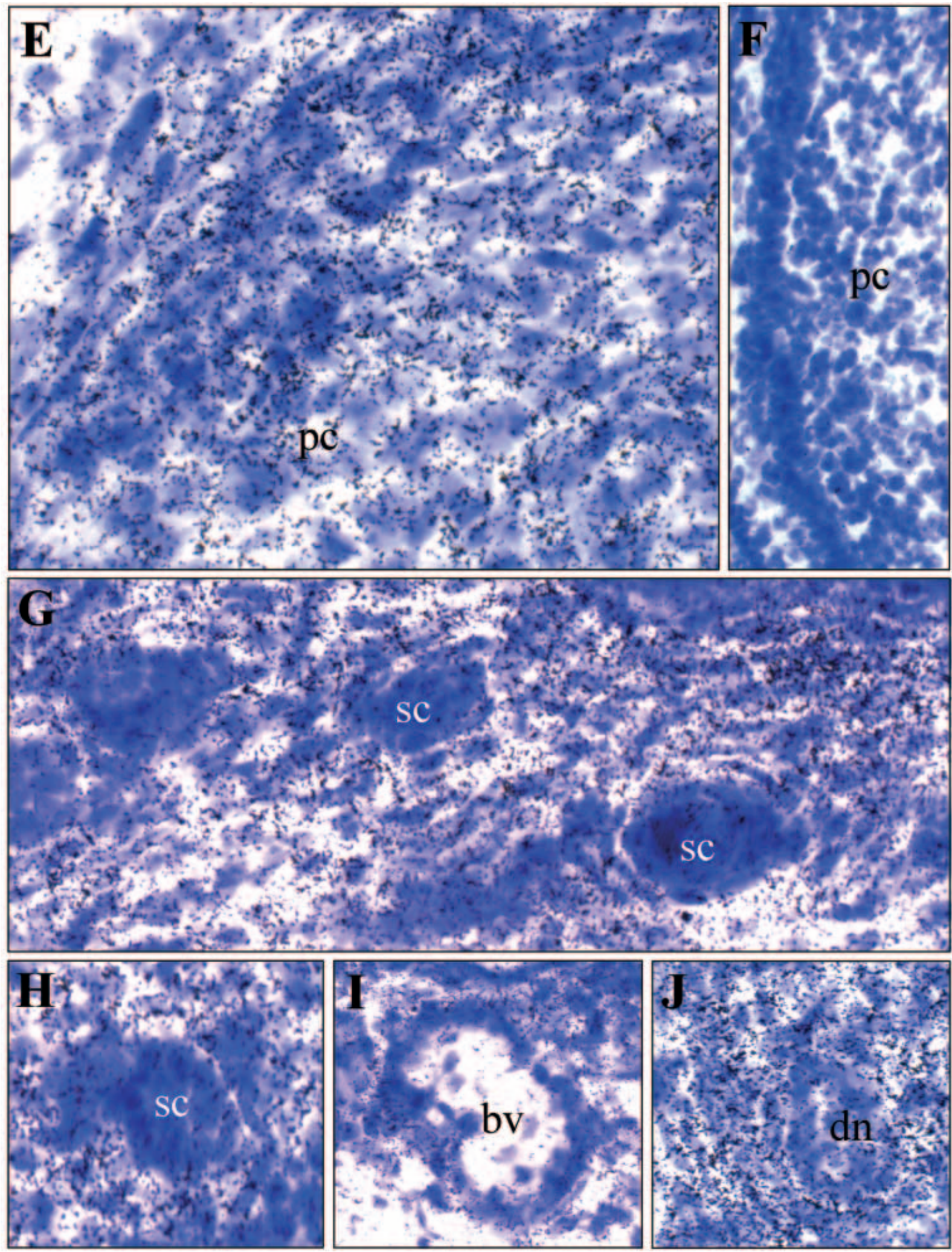

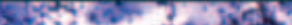
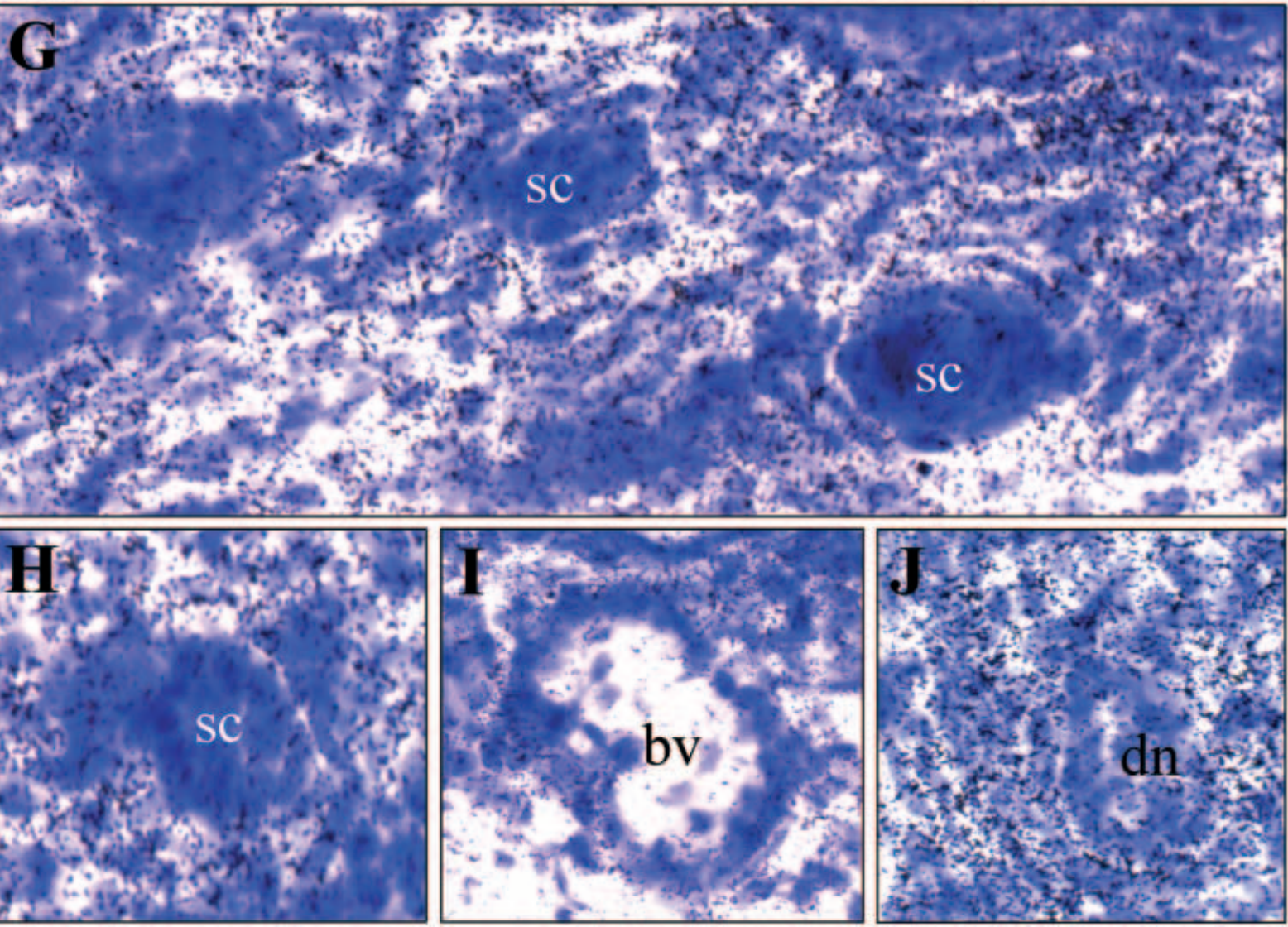

Figure $2(\mathrm{E})$ to $(\mathrm{J})$. 
to day $3(0 \cdot 5 \mu \mathrm{g}$, on alternate days $)$ with high doses of DES caused an increase of $30 \pm 3 \%$ in aromatase protein expression $(n=5 ; \quad P<0 \cdot 001)$ compared with vehicle-treated rats (Fig. 5). However, low doses of DES ( $1 \mu \mathrm{g}$ for mother, $0.005 \mu \mathrm{g}$ for neonate) had insignificant effects on penile aromatase expression. Similarly, treatment with androgens (DHT and testosterone) up-regulated aromatase expression in the penis by $70 \pm 7 \%$ (DHT) and $40 \pm 6 \%$ (testosterone) (3-day-old penis) (Fig. 5).

The effects of treatment with the potent synthetic estrogen, DES, and with the androgens, DHT and testosterone, on aromatase gene expression in the 3-day-old penis corresponded with data obtained by immunoblot analysis, as revealed by real-time PCR above - i.e. high doses of DES increased the levels of the aromatase gene, whereas low doses had no effect; both testosterone and DHT upregulated aromatase gene expression (Fig. 6A).

High doses of DES markedly increased estrogen levels $(39 \cdot 3 \pm 7 \mathrm{pg} / \mathrm{mg})$ in penile tissues compared with control $(17 \pm 4 \mathrm{pg} / \mathrm{mg})$, whereas low DES upregulated estrogen only slightly $(20 \cdot 6 \pm 4 \mathrm{pg} / \mathrm{mg})$, consistent with data shown above. Surprisingly, although DHT upregulated aromatase protein and mRNA levels, it had no effect on tissue levels of penile estrogen $(17 \cdot 4 \pm 3 \cdot 6 \mathrm{pg} / \mathrm{mg}$ ) (Fig. 6), whereas testosterone upregulated estrogen concentrations in the penis $(26 \cdot 7 \pm 5 \mathrm{pg} / \mathrm{mg})$, consistent with its effects on aromatase expression.

\section{Discussion}

The present study provides evidence of local estrogen production in the penis expressed age-dependently using Western blots, enzyme immunoassay, real-time PCR, immunohistochemistry and in situ hybridization. Aromatase protein and mRNA are (1) localized in a variety of cells found in different penile compartments, (2) expressed age-dependently in the penis, declining with advancement of age, in parallel with tissue estrogen levels, and (3) upregulated by exogenous sex hormone steroids (testosterone, DHT, DES). Interestingly, these findings correlate with our recent report on the penile ER and confirm our earlier speculation that a local autocrine/paracrine estrogen-ER system exists in the penis, which may play a role in development in association with the classic sex steroid hormone, androgen.

Real-time PCR analysis showed significant expression of aromatase gene in the penis. This was further confirmed by in situ hybridization analysis, which revealed localization of aromatase mRNA in various penile compartments. Immunoblots, enzyme immunoassay and immunofluorescence showed that aromatase mRNA was translated into protein. On Western blots, we detected a single and distinct band migrating at $54 \mathrm{kDa}$. This molecular mass is very close to the values reported for seminiferous tubules and crude germ cells in mature rats $(55 \mathrm{kDa})$ (Levallet et al. 1998) and in both infant and adult testicular cell lines in humans (53 kDa) (Brodie et al. 2001). Levels of penile aromatase protein and estrogen concentrations were strikingly similar across ages, as revealed by enzyme immunoassay, implying that penile aromatase is not only transcribed and translated locally, but is functionally active in the penis where it irreversibly converts androgens into estrogens. Two types of promoters for aromatase have been identified in the rat testis, namely proximal promoter II and distal promoter I.4, which are also present in the ovary and adipose/bone tissues respectively (Bourguiba et al. 2003, Simpson 2003). However, at this point, the specific promoters of penile aromatase are not known.

Earlier studies have shown that testosterone downregulates rat corpora cavernosa androgen receptors via aromatization to estrogen, an effect blocked by aromatase inhibitor (Lin et al. 1993). Other studies, using human penile smooth muscle cell lines, reported that estrogen attenuates

\footnotetext{
Figure 2 In situ hybridization analysis showing expression of aromatase mRNA in the ovary and penis of pregnant and postnatal day 3 rats respectively. Abundant expression was observed in (A) the corpus luteum of ovary (Cl) (inset: high magnification), (B) penile spongiosus (ps) and urethra (u), (E) cavernosum (pc), $(G, H)$ sensory corpuscles (sc), (I) blood vessels (bv), and (J) dorsal nerve (dn). When the cold probe was added in excess of the hot probe, the signal disappeared in penile spongiosus (ps) and urethra $(u)(C)$ and in penile cavernosum (pc) (F). Magnification $\times 200$. At high magnification $(\times 400)$, clear aromatase signal was seen in penile spongiosus $(p s)$, and urethral luminal and basal epithelium (D).
} 
A

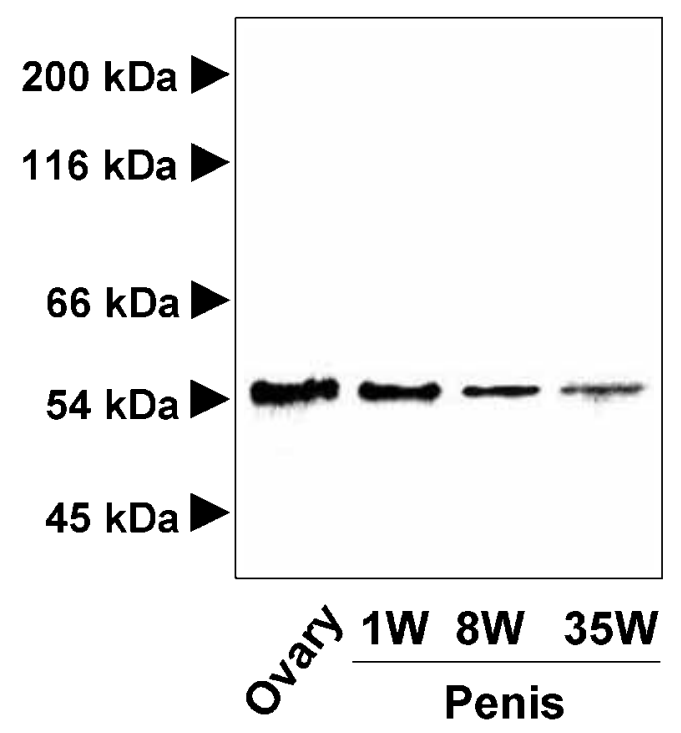

B

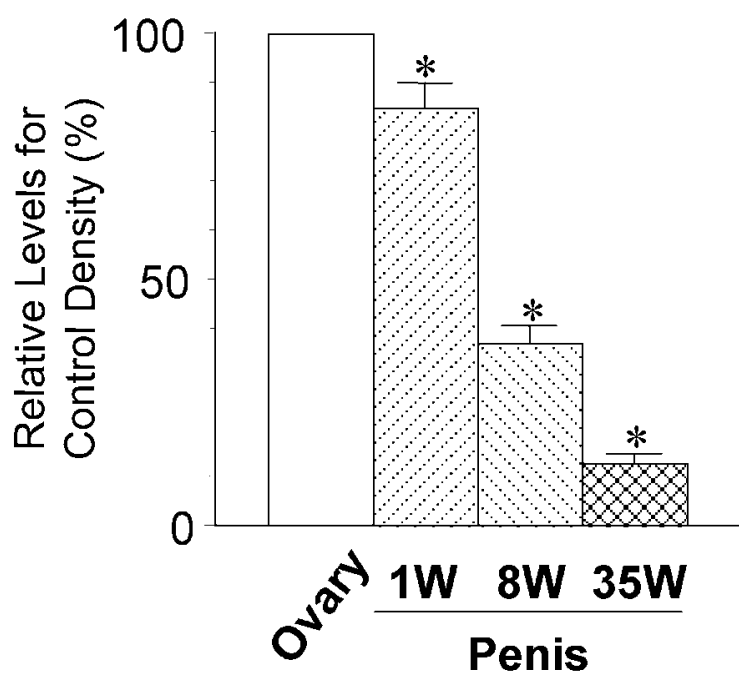

Figure 3 (A) Immunoblot analysis of aromatase protein of adult rat ovary (lane 1) (positive tissue control) and penile tissues of 1-, 8-, 35-week-old rats (1W, 8W, 35W; lanes 2-4). Representative blots of aromatase protein in the ovary and penises are shown. The experiments were conducted by loading equal amounts of ovarian and penile proteins in each lane. (B) Bar graph summarizing the immunoblot data. Bands were quantified by densitometry, plotted and expressed as a percentage of the ovarian band. Results are shown as the means \pm S.D. of five experiments. ${ }^{\star} P<0.01$ compared with ovary.

proliferation and induces expression of oxytocin receptors in these cells (Crescioli et al. 2003, Vignozzi et al. 2004). These findings are consistent with the present data that demonstrate aromatase in various penile compartments. One of the key novel findings of the present study is that aromatase and estrogen in the penis are abundant and are regulated age-dependently, with levels in the first week of life almost resembling those of the ovary, the classical tissue. It is noteworthy that this pattern of aromatase expression resembles those of penile ER reported recently (Jesmin et al. 2002), confirming our earlier speculation that estrogen's role in the penis may be functional predominantly during development, particularly during the neonatal period (Jesmin et al. 2002). It is possible that expression of penile aromatase, like testicular aromatase, appears prenatally to influence the initial stages of penile differentiation (Greco \& Payne 1994).

The functional significance of local extra-gonadal estrogen in cell physiology and pathophysiology is just beginning to be appreciated in tissues such as the nervous, adipose and adrenal gland (Simpson 2003). Although the role of estrogen in the penis is currently unclear, evidence supporting a role for local estrogen in penile events is beginning to emerge (Greene et al. 1939, Stillman 1982, Iguchi et al. 1990, North \& Golding 2000, Jesmin et al. 2002, Crescioli et al. 2003, Dietrich et al. 2004, Vignozzi et al. 2004). It is interesting to note that aromatase, like ER, is broadly expressed in similar penile compartments (urethra, spongiosus, cavernosus) and cell types (neuronal, vascular, stromal and epithelial) (Jesmin et al. 2002), suggesting the existence of a local autocrine and/or paracrine system of estrogen action in penile cells. The diversity of cell types expressing aromatase and ER indicates the complexity of estrogen's potential functions in the penis (Jesmin et al. 2002). Such functions may, in general, include regulation of development, differentiation and, specifically, may involve function of penile blood vessels, nerves, stromal and epithelial cells (Patrone et al. 1999, 2000, Calles-Escandon \& Cipolla 2001, Papka et al. 2001, Jesmin et al. 2002). Indeed, we have previously shown that caspase 3 and Bcl-2, respectively, co-localize with ER- $\alpha$ in the sensory corpuscles of the glans penis, suggesting that estrogen acting in an autocrine fashion via ER- $\alpha$ may promote survival and/or viability of sensory neurons in the glans penis (Jesmin et al. 2002). The use of aromatase knockout mice should provide more insight into the role of aromatase in penile 


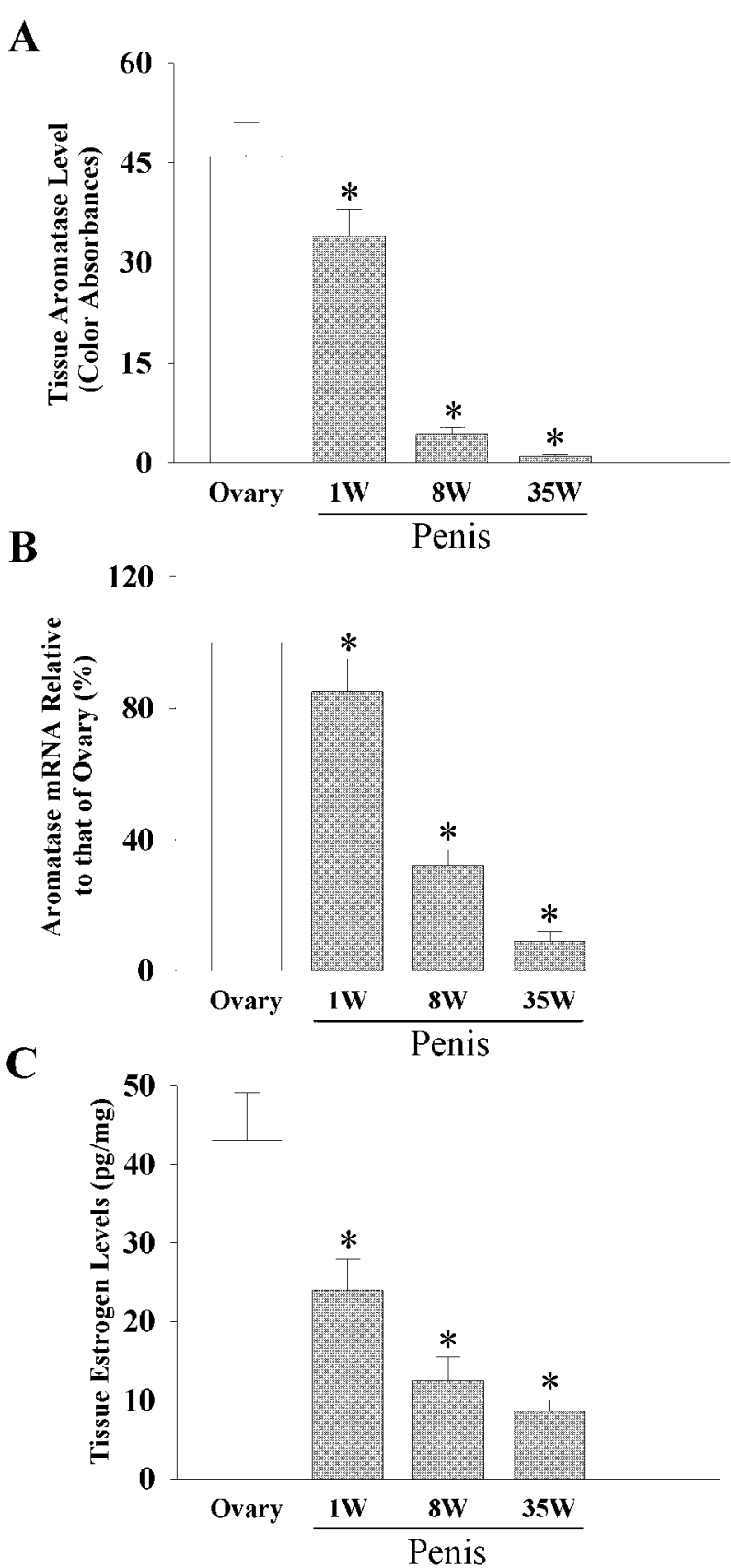

Figure 4 (A) Levels of aromatase in rat adult ovary and penises at 1, 8, 35 weeks $(1 \mathrm{~W}, 8 \mathrm{~W}, 35 \mathrm{~W})$ as determined by ELISA. (B) Gene expression level of aromatase in the penile tissues of 1-, 8-, and 35-week-old rats and in the adult ovary which was used as a positive control tissue. Expression of aromatase mRNA was quantitatively evaluated by real-time PCR. (C) Tissue levels of $17 \beta$-estradiol in rat adult ovary and rat penile tissues at 1 , 8 , and 35 weeks. The $17 \beta$-estradiol level was determined by enzyme immunoassay. Data are means \pm S.D. $(n=6-7)$. ${ }^{\star} P<0.01$ compared with the corresponding values obtained in the ovary.
A
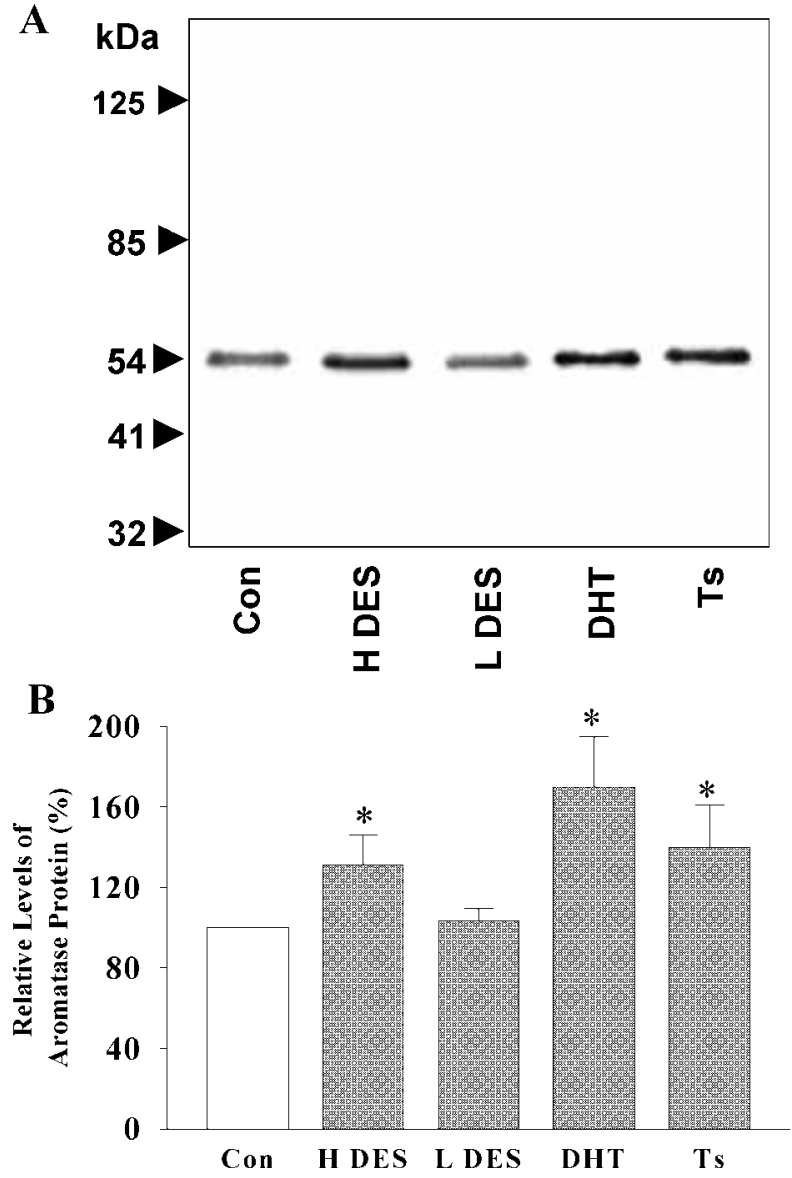

Figure 5 Immunoblot analysis for aromatase in the penile tissues at postnatal day 3 after treatment with vehicle (Con) (lane 1), high dose of diethylstilbesterol $(\mathrm{H}$ DES) (lane 2), low dose of diethylstilbesterol (L DES) (lane 3), dihydrotestosterone (DHT) (lane 4) and testosterone (Ts) (lane 5), starting from day 10 of pregnancy. (A) Representative blots of aromatase protein in penises. The experiments were conducted by loading equal amounts of penile proteins in each lane. (B) Bar graph summarizing the immunoblot data. Data were quantified, plotted and expressed as a percentage of untreated penis (Con). Data are shown as the means \pm S.D. of five experiments. ${ }^{*} P<0.01$ compared with control.

events, even though findings of earlier studies show that these mice are fertile and capable of copulating (Robertson et al. 1999). However, it is important to note that transgenic mice expressing human aromatase, with high concentrations of circulating estrogen and prolactin and low testosterone, are infertile and display multiple structural and functional male reproductive abnormalities (Li et al. 2003). These findings may emphasize the 
A

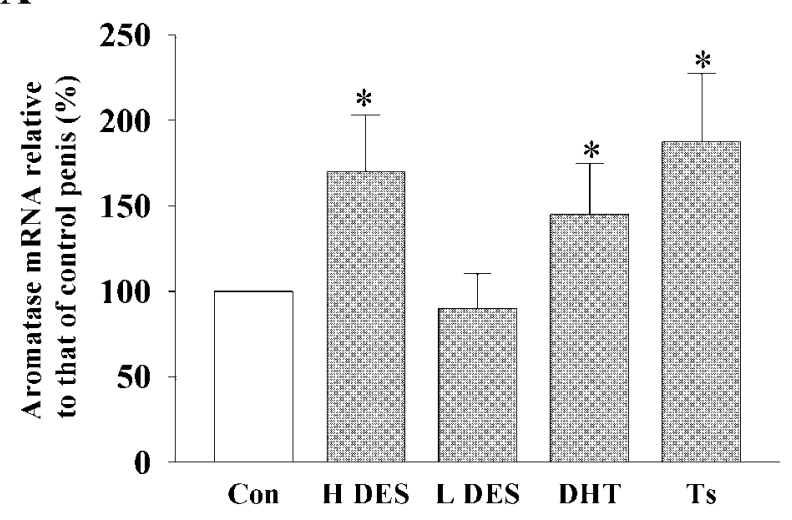

B

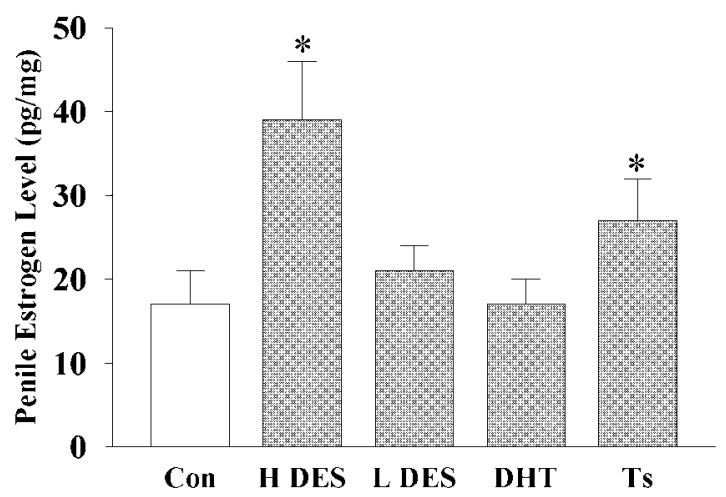

Figure $6(A)$ Messenger RNA expression of aromatase in the penile tissues at postnatal day 3 after treatment with vehicle control (Con), high doses of diethylstilbesterol (H DES), low doses of diethylstilbesterol (L DES), dihydrotestosterone (DHT) and testosterone (Ts), starting from day 10 of pregnancy up to postnatal day 2 , as revealed by real-time PCR.

Results were expressed as relative values of the control rat penis. (B) The 17 $\beta$-estradiol concentrations, determined by enzyme immunoassay, in penile tissues at postnatal day 3 after treatment with vehicle (Con), high dose of diethylstilbesterol (H DES), low dose of diethylstilbesterol (L DES), dihydrotestosterone (DHT) and testosterone (Ts), starting from day 10 of pregnancy up to postnatal day 2. Data are means \pm S.D. $(n=6)$. ${ }^{\star} P<0.01$ compared with the value obtained in the control penis.

importance of the local estrogen:androgen balance in male reproduction.

In the local cellular physiology of sex steroidsensitive cells, the androgen:estrogen ratio may be more important than single hormone action (Carreau et al. 1999, Simpson 2003). This ratio is mainly controlled by aromatase and its expression is regulated by many factors, including estrogen, testosterone, DHT, follicle-stimulating hormone, luteinizing hormone, cyclic AMP, growth factors, tumor necrosis factor- $\alpha$ and interleukin-1 (Carreau et al. 2002, Chen et al. 2002, Simpson 2003). The present study begins to address the regulatory effects of estrogens and androgens on penile aromatase mRNA and protein. We demonstrate that testosterone, DHT and DES, when administered prenatally, upregulate levels of penile aromatase mRNA and protein postnatally. However, unlike DES and testosterone, DHT had no effect on local penile estrogen concentration, suggesting that the influence DHT on aromatase is limited to transcription and translation, but not to aromatase activity. The regulation of aromatase expression is complex and is tissue specific, with possibly one specific promoter for each tissue (Carreau et al. 2002, Simpson 2003). For instance, proximal promoter II regulates expression of ovarian aromatase and distal promoter I.1 modulates placental aromatase, whereas distal promoter I.4 regulates aromatase expression in the adipose and bone tissues (Simpson 2003). The effects of the sex steroid hormones on penile aromatase, as demonstrated here, are not surprising, in that aromatase promoters express response elements of these hormones and have similar effects on aromatase expression in other tissues (Lephart 1996, Callard et al. 2001, Carreau et al. 2002, Simpson 2003). For example, estrogen increased expression of aromatase in zebrafish brain, whereas DHT and testosterone were ineffective (Kishida et al. 2001). In another study, androgens in the brain region regulated aromatase in a region- and gender-specific manner (MacLusky et al. 1994). More studies are needed in future to identify the specific promoter and transcripts of penile aromatase and to determine in more detail the specific regulatory pathways of testosterone, DHT and estrogen. Equally important will be the effects of environmental estrogens.

The interrelationship between testosterone and estrogen biosynthesis has made it hard to differentiate their precise effects. Indeed, much of the conventional knowledge on the biological effects attributed to androgen in penile events may represent effects of estrogen or androgen plus estrogen; for example, previously androgen was thought to restrict penile growth via downregulation of its receptor (Takane et al. 1990). However, a later study, which utilized specific 
agonist and antagonist/inhibitors for sex steroids and enzymes, demonstrated that estrogen synthesized from testosterone down-regulates the androgen receptor, and not testosterone, as previously thought (Lin et al. 1993). Thus, there is a need to re-visit this subject since we are now equipped with a variety of research tools, such as animal models lacking ER, androgen receptor, estrogen, DHT and their specific inhibitors or antagonists, to better understand this subject.

In summary, the novel findings of this study, demonstrating the presence, age- and sex steroiddependent regulation of aromatase in the penis, provides further evidence of a role for local estrogen in penile events and the interaction of the estrogen and androgen systems. It is essential that future studies determine the specific promoter of penile aromatase and investigate the exact mechanisms and factors regulating it.

\section{Acknowledgements}

This work was supported, in part, by a Grant-inAid for Scientific Research from the Ministry of Education, Science, Sports and Culture of Japan, and by Health Sciences Research Grants for Comprehensive Research on Aging and Health from the Ministry of Health, Welfare and Labor of Japan.

\section{References}

Attal J 1969 Levels of testosterone, androstenedione, estrone and oestradiol-17 $\beta$ in the testes of fetal sheep. Endocrinology $\mathbf{8 5}$ 280-289.

Bourguiba S, Genissel C, Lambard S, Bouraima H \& Carreau S 2003 Regulation of aromatase gene expression in Leydig cells and germ cells. Fournal of Steroid Biochemistry and Molecular Biology 2003 86 335-343.

Brodie A, Inkster S \& Yue W 2001 Aromatase expression in the human male. Molecular and Cellular Endocrinology 178 23-28.

Callard GV, Tchoudakova AV, Kishida M \& Wood E 2001 Differential tissue distribution, developmental programming, estrogen regulation and promoter characteristics of cyp 19 genes in teleost fish. Foumal of Steroid Biochemistry and Molecular Biology 79 305-314.

Calles-Escandon J \& Cipolla M 2001 Diabetes and endothelial dysfunction: a clinical perspective. Endocrine Reviews 22 $36-52$.

Carreau S, Genissel C, Bilinska B \& Levallet J 1999 Sources of oestrogen in the testis and reproductive tract of the male. International fournal of Andrology 22 211-223.

Carreau S, Bourguiba S, Lambard S, Galeraud-Denis I, Genissel C \& Levallet J 2002 Reproductive system: aromatase and estrogens. Molecular and Cellular Endocrinology 193 137-143.
Chen S, Itoh T, Wu K, Zhou D \& Yang C 2002 Transcriptional regulation of aromatase expression in human breast tissue. Fournal of Steroid Biochemistry and Molecular Biology 83 93-99.

Crescioli C, Maggi M, Vannelli GB, Ferruzzi P, Granchi S, Muratori M, Forti G, Serio M \& Luconi M 2003 Expression of functional estrogen receptors in human fetal male external genitalia. Fournal of Clinical Endocrinology and Metabolism 88 $1815-1824$

Dietrich W, Haitel A, Huber JC \& Reiter WJ 2004 Expression of estrogen receptors in human corpus cavernosum and male urethra. Fournal of Histochemistry and Cytochemistry $\mathbf{5 2}$ 355-360.

Free MJ \& Jaffe RA 1979 Collection of rete testis fluid from rats without previous efferent duct ligation. Biology of Reproduction 20 269-278.

Goldzieher JW \& Roberts IS 1952 Identification of oestrogen in the human testis. Fournal of Clinical Endocrinology and Metabolism 12 143-150.

Greco TL \& Payne AH 1994 Ontogeny of expression of the genes for steroidogenic enzymes, P450 side-chain cleavage, 3 betahydroxysteroid dehydrogenase, P450 17 alpha-hydroxylase/ C17-20 and P450 aromatase, in fetal mouse gonads. Endocrinology $135262-268$.

Greene R, Burrill M \& Ivy A 1939 Experimental intersexuality: modification of sexual development of the white rat with a synthetic estrogen. Proceedings of the Society for Experimental Biology and Medicine 41 169-170.

Hess RA, Bunick D, Lee KH, Bahr J, Taylor JA, Korach KS \& Lubahn DB 1997a A role for estrogen in the male reproductive system. Nature 390 509-512.

Hess RA, Gist DH, Bunick D, Lubahn DB, Farrell A, Bahr J, Cooke PS \& Greene GL $1997 b$ Estrogen receptor (alpha and beta) expression in the excurrent ducts of the adult male rat reproductive tract. Fournal of Andrology 18 602-611.

Iguchi T, Irisawa S, Uesugi Y, Kusunoki S \& Takasugi N 1990 Abnormal development of the os penis in male mice treated neonatally with tamoxifen. Acta Anatomica $\mathbf{1 3 9}$ 201-208.

Jesmin S, Mowa CN, Matsuda N, Salah-eldin A, Togashi H, Sakuma I, Hattori Y \& Kitabatake A 2002 Evidence for a potential role of estrogen in the penis: detection of estrogen receptor- $\alpha$ and $-\beta$ messenger ribonucleic acid and protein. Endocrinology $1434764-4774$.

Kishida M, McLellan M, Miranda JA \& Callard GV 2001 Estrogen and xenoestrogens upregulate the brain aromatase isoform (P450 aromB) and perturb markers of early development in zebrafish (Danio rerio). Comparative Biochemistry and Physiology. Part B. Biochemistry and Molecular Biology 129 261-268.

Koike S, Sakai M \& Muramatsu M 1987 Molecular cloning and characterization of rat estrogen receptor cDNA. Nucleic Acids Research 15 2499-2513.

Kuiper GG, Enmark E, Pelto-Huikko M, Nilssons S \& Gustatsson J-A 1996 Cloning of a novel estrogen receptor expressed in the rat prostate and ovary. PNAS 93 5925-5930.

Lauber ME \& Lichtensteiger W 1994 Pre- and postnatal ontogeny of aromatase cytochrome $\mathrm{P} 450$ messenger ribonucleic acid expression in the male rat brain studied by in situ hybridization. Endocrinology 135 1661-1668.

Leach RB, Maddock WO, Tokuyama I, Paulsen CA \& Nelson WO 1956 Clinical studies of testicular hormone production. Recent Progress in Hormone Research 12 377-397.

Lephart ED 1996 A review of brain aromatase cytochrome P450. Brain Research Reviews 22 1-26.

Levallet J, Bilinska B, Mittre H, Genissel C, Fresnel J \& Carreau S 1998 Expression and immunolocalization of functional cytochrome P450 aromatase in mature rat testicular cells. Biology of Reproduction $\mathbf{5 8}$ 919-926. 
Li X, Makela S, Streng T, Santti R \& Poutamen M 2003 Phenotype characteristics of transgenic male mice expressing human aromatase under ubiquitin $\mathrm{C}$ promoter. Fournal of Steroid Biochemistry and Molecular Biology 86 469-476.

Lin MC, Rajfer J, Swerdloff RS \& Gonzalez-Cadavid NF 1993 Testosterone down-regulates the levels of androgen receptor mRNA in smooth muscle cells from the rat corpora cavernosa via aromatization to estrogens. Fournal of Steroid Biochemistry and Molecular Biology 45 333-343.

Longcope C, Goldfield SRW, Brambilla DJ \& McKinlay J 1990 Androgens, oestrogens and sex hormone-binding globulin in middle-aged men. Fournal of Clinical Endocrinology and Metabolism 71 $1442-1446$

Lowry OH, Rosebrough NJ, Farr AL \& Randall RJ 1951 Protein measurement with the folin phenol reagent. Fournal of Biological Chemistry 193 265-275.

MacLusky NJ, Walters MJ, Clark AS \& Toran-Allerand CD 1994 Aromatase in the cerebral cortex, hippocampus, and mid-brain: ontogeny and developmental implications. Molecular and Cellular Neurosciences 5 691-698.

McKinnell C, Atanassova N, Williams K, Fisher JS, Walker M, Turner KJ, Saunders PTK \& Sharpe RM 2001 Suppression of androgen action and the induction of gross abnormalities of reproductive tract in male rats treated neonatally with diethylstilbesterol. Fournal of Andrology 22 323-338.

Matsuda N, Hattori Y, Gando S, Akaishi Y, Kemmotsu O \& Kanno M 1999 Diabetes-induced down-regulation of $\beta_{1}$-adrenoceptor mRNA expression in rat heart. Biochemical Pharmacology 58 881-885.

Meistrich ML, Hughes TJ, Ambus T \& Bruce WR 1977 Spermatogenesis in hybrid mice treated with oestrogen and testosterone. Fournal of Reproduction and Fertility 50 75-81.

Morse WI, Clark AF, MacLeod SC, Ernst WA \& Grossee CL 1962 Urine oestrogen responses to human chorionic gonadotropin in gonad of old and hypogonadal men. Fournal of Clinical Endocrinology and Metabolism 22 678-685.

Mowa CN \& Iwanaga T 2000 Differential distribution of oestrogen receptor- $\alpha$ and $-\beta$ mRNAs in the female reproductive organ of the rats as revealed by in situ hybridization. Fournal of Endocrinology $\mathbf{1 6 5}$ 59-66.

Mowa CN \& Iwanaga T $2001 a$ Expression of estrogen receptor $\alpha$ and $\beta$ mRNAs in the male reproductive system of the rat as revealed by in situ hybridization. Fournal of Molecular Endocrinology $26165-174$.

Mowa CN \& Iwanaga T $2001 b$ Developmental changes of the oestrogen receptor- $\alpha$ and $-\beta$ mRNAs in the female reproductive organ of the rats - an analysis by in situ hybridization. Fournal of Endocrinology 167 363-369.

North K \& Golding J 2000 A maternal vegetarian diet in pregnancy is associated with hypospadias. The ALSPAC Study Team. Avon longitudinal study of pregancy and childhood. BfU International 85 $107-113$.
Papka RE, Storey-Workley M, Shughrue PJ, Merchenthaler I, Collins JJ, Usip S, Saunders PTK \& Shupnik M 2001 Estrogen receptor- $\alpha$ and $-\beta$ immunoreactivity and mRNA in neurons of sensory and autonomic ganglia and spinal cord. Cell and Tissue Research 304 193-214.

Patrone C, Andersson S, Korhonen L \& Lindholm D 1999 Estrogen receptor-dependent regulation of sensory neuron survival in developing dorsal root ganglion. PNAS 96 10905-10910.

Patrone C, Pollio G, Vegeto E, Enmark E, de Curitis I, Gustafsson J-Å \& Maggi A 2000 Estradiol induces differential neuronal phenotypes by activating estrogen receptor $\alpha$ and $\beta$. Endocrinology 141 1839-1845.

Pereyra-Martinez AC, Roselli CE, Stadelman HL \& Resko JA 2001 Cytochrome P450 aromatase in testis and epididymis of male rhesus monkeys. Endocrine 16 15-19.

Raeside JJ \& Renaud RL 1983 Estrogen and androgen production by purified Leydig cells of mature boars. Biology of Reproduction 28 727-733.

Robertson KM, O’Donnel L, Jones ME, Meachem SJ, Boon WC, Fisher CK, Graves KH, McLachlan RI \& Simpson ER 1999 Impairment of spermatogenesis in mice lacking a functional aromatase (cyp 19) gene. PNAS 96 7986-7991.

de Ronde W, Pols HAP, van Leeuwen JPTM \& de Jong FH 2003 The importance of oestrogens in males. Clinical Endocrinology $\mathbf{5 8}$ 529-542.

Sar M \& Welsch F 1999 Differential expression of estrogen receptor- $\beta$ and receptor- $\alpha$ in the rat ovary. Endocrinology 140 963-971.

Simpson ER 2003 Sources of estrogen and their importance. Fournal of Steroid Biochemistry and Molecular Biology 86 225-230.

Stillman RJ 1982 In utero exposure to diethylstilbesterol: adverse effects on the reproductive tract and reproductive performance of male and female offspring. American Fournal of Obstetrics and Gynecology 142 905-921.

Takane KK, George FW \& Wilson JD 1990 Androgen receptor of rat penis is down-regulated by androgen. American fournal of Physiology 258 E46-E50.

Vignozzi L, Filippi S, Luconi M, Morelli A, Mancina R, Marini M, Vannelli GB, Granchi S, Orlando C, Gelmini S, Ledda F, Forti G \& Maggi M 2004 Oxytocin receptor is expressed in the penis and mediates an estrogen-dependent smooth muscle contractility. Endocrinology 145 1823-1834.

Wiszniewska B 2002 Primary culture of the rat epididymal epithelial cells as a source of oestrogen. Andrologia 34 180-187.

Zondek B 1934 Mass excretion of oestrogenic hormone in the urine of the stallion. Nature 193 209-210.

Received 23 May 2004

Accepted 19 July 2004 